IZA DP No. 5212

Why Have Lending Programs Targeting Disadvantaged Small-Business Borrowers Achieved So Little Success in the United States?

Timothy Bates

Magnus Lofstrom

Lisa Servon

September 2010 


\title{
Why Have Lending Programs Targeting Disadvantaged Small-Business Borrowers Achieved So Little Success in the United States?
}

\author{
Timothy Bates \\ Wayne State University \\ Magnus Lofstrom \\ Public Policy Institute of California \\ and IZA \\ Lisa Servon \\ New School University
}
Discussion Paper No. 5212
September 2010

\author{
IZA \\ P.O. Box 7240 \\ 53072 Bonn \\ Germany \\ Phone: +49-228-3894-0 \\ Fax: +49-228-3894-180 \\ E-mail: iza@iza.org
}

\begin{abstract}
Any opinions expressed here are those of the author(s) and not those of IZA. Research published in this series may include views on policy, but the institute itself takes no institutional policy positions.

The Institute for the Study of Labor (IZA) in Bonn is a local and virtual international research center and a place of communication between science, politics and business. IZA is an independent nonprofit organization supported by Deutsche Post Foundation. The center is associated with the University of Bonn and offers a stimulating research environment through its international network, workshops and conferences, data service, project support, research visits and doctoral program. IZA engages in (i) original and internationally competitive research in all fields of labor economics, (ii) development of policy concepts, and (iii) dissemination of research results and concepts to the interested public.
\end{abstract}

IZA Discussion Papers often represent preliminary work and are circulated to encourage discussion. Citation of such a paper should account for its provisional character. A revised version may be available directly from the author. 
IZA Discussion Paper No. 5212

September 2010

\section{ABSTRACT}

\section{Why Have Lending Programs Targeting Disadvantaged Small-Business Borrowers Achieved So Little Success in the United States?}

Small business lending programs designed to move disadvantaged low-income people into business ownership have been difficult to implement successfully in the U.S. context. Based in part on the premise that financing requirements are an entry barrier limiting the ability of aspiring entrepreneurs to create small businesses, these programs are designed to alleviate such barriers for low net-worth individuals with limited borrowing opportunities. Our analysis tracks through time nationally representative samples of adults to investigate the role of financial constraints and other factors delineating self-employment entrants from nonentrants. Paying particular attention to lines of business most accessible to adults lacking college credentials and substantial personal net worth, our analysis yields no evidence that financial capital constraints are a significant barrier to small-firm creation.

JEL Classification: J15, L26

Keywords: self-employment, entrepreneurship, micro-lending

Corresponding author:

Magnus Lofstrom

Public Policy Institute of California

500 Washington Street, Suite 600

San Francisco, CA 94111

USA

E-mail: lofstrom@ppic.org 


\section{Introduction}

Small business lending programs subsidized by government and non-profit agencies are often designed to move disadvantaged people into business ownership. Typifying widespread sentiment about the need to encourage self help among lowincome Americans, former New York mayor Giuliani offered this advice; “If you can't get a job, start a small business, start a little candy store. Start a little newspaper stand. Start a lemonade stand" (Deparle 1998, p.89).

In addition to loans, these programs sometimes provide business training to aspiring and actual small-firm owners. Although attractive in theory, bootstrap rhetoric has proven more difficult to implement in practice in the US context. The current consensus opinion of program effectiveness in moving disadvantaged clients into ownership of viable business is well stated by Nancy Jurik: "Fostering successful enterprises takes more than a brief training course and a small business loan when clients are poor or otherwise highly disadvantaged" (p. 202, 2005).

In the case of microenterprise lending programs (MLPs), popular since the 1990s, demand for loans has been surprisingly weak. Low loan volume has exacerbated by steep administrative costs per dollar lent. In combination with the high default rates typifying loans flowing to disadvantaged clients, microenterprise lending has produced high costs relative to benefits (AEO, 2002; Servon, 2006). While program sponsors often expect MLPs to lend aggressively and to incur low default rates, the opposite outcome, in practice, has been the norm. 
What went wrong? An impressive body of academic research suggests that successful small firm entry and operation normally requires working capital to finance day-to-day operations. Most firms need capital to invest in equipment, inventory, and the like. Absent adequate capitalization, it is difficult for most firms to get off the ground. Subsidized small business lending programs have frequently targeted low-income minority clients, a group known to face multiple capital constraints. The evidence documenting low personal wealth levels and limited borrowing power among black and Hispanic Americans in particular is overwhelming (Fairlie \& Robb, 2008; Cavalluzzo \& Wolken, 2005). In his analysis of self-employment entry among African Americans, Fairlie observes that "racial differences in asset levels play an important role in explaining the racial gap in the entry rate" (1999). Indeed, such evidence has been widely cited by lenders seeking to justify existing and envisioned programs to potential funding sources. The reality of restricted access to capital powerfully suggests that aspiring minority entrepreneurs may benefit from expanded loan access.

Our primary goal is to explain the paradox of supposed binding capital constraints limiting entry into self employment, coexisting with the reality of low demand for microenterprise loans. Aspiring minority entrepreneurs are precisely the ones most negatively impacted by low personal wealth holdings and limited access to bank credit. These capital constraints, if alleviated, would logically turn aspirations into reality for many potential minority owners of small businesses. Yet, although active microenterprise lending programs most often target capital- 
constrained minority borrowers, loan demand nonetheless has been surprisingly weak.

We analyzed Bureau of the Census Survey of Income and Program Participation (SIPP) data to track self-employment entry through time. This study follows a representative nationwide sample of potential entrants to self employment and small business ownership over a three-year period. Among 21,064 minorities who were initially not self employed, nearly four percent of them subsequently became active business owners. Our analysis identifies characteristics delineating entrants from adults choosing not to pursue self employment, paying particular attention to the wealth holdings of each. Our analysis initially focuses upon entry into business ownership among African Americans, Latinos, and Asians because the targeted client groups of subsidized lending programs are most often minorities.

Examining first the traits differentiating minorities entering into small business ownership from nonentrants, we find that entry into the types of businesses most accessible to disadvantaged persons is not being restricted by wealth constraints. Aspiring minority entrepreneurs possessing little or no personal wealth are just as likely to become self employed as those with net worth in the $\$ 25,000$ to $\$ 50,000$ range.

Recognizing heterogeneity in business ownership requirements across different industry groups, we employed a classification of firms by financial- and human-capital intensiveness, or entry barriers. We employed the concept of high- 
and low-barrier industry subgroups to demonstrate that determinants of entry differ sharply across the sectors. Our analysis yields no evidence that financial capital constraints are a significant barrier to firm creation in the low-barrier lines of business most often targeted for entry by subsidized loan program clients. Significant capital constraints do restrict entry in some lines of business, manufacturing, for example. Indeed, we find that individuals possessing net worth of $\$ 150,000$ or more are more likely to become small-firm owners in high-barrier fields than people in lower wealth brackets. Yet this finding reinforces our conclusion that subsidized loans fail to ease applicable entry barriers. Clients targeted by these programs are concentrated at the bottom of the wealth distribution, not the top. Entry into capital-intensive fields is simply not likely to be impacted by extending small loans to poor aspiring entrepreneurs.

\section{The Track Record of Prominent Subsidized Small Business Loan Programs}

Our review of subsidized lending programs targeting potential and actual minority-owned business ventures over past decades is illustrative in nature and does not constitute a comprehensive policy overview or evaluation. We have intentionally emphasized difficulties arising as implementation of policy objectives reveals incompatibilities between what the resources employed to fulfill policy goals are capable of achieving, as opposed to what the designers of those policies had hoped to achieve. The gap between objectives and outcomes is often wide. Thus, small-business lending programs commonly go through distinct implementation phases as they attempt to cope pragmatically with the gap between 
the expectations of their designers, versus the reality of what they are capable of achieving.

\section{Economic Opportunity Loans}

The provision of subsidized loans to encourage small-business ownership among low-income adults has been a component of poverty alleviation strategies in the United States since the early 1960s. Under President Lyndon Johnson's War on Poverty, the Economic Opportunity Loan (EOL) program was authorized under the Economic Opportunity Act in 1964. EOL loans were long-term loans extended to disadvantaged business owners - largely minority-business borrowers -- by the U.S. Small Business Administration (SBA). Eligibility requirements were initially interpreted to mean that loans would be extended solely to persons living in poverty. Eligibility was later expanded to include disadvantaged persons who "had been denied the opportunity to compete in business on equal terms" (U.S. Small Business Administration 1970, p.4).

A comprehensive study of all EOL loans to African Americans and nonminority whites, funded between 1967 and 1970, to persons starting small businesses in New York City, Boston and Chicago tracked loan repayment through November 1973. Overall, 124 loans to finance entry were identified, including 80 received by black borrowers and 40 to whites. As of November 1973, 46 of these loans were either current or fully repaid, 68 had been written off as uncollectible, and 10 were delinquent but still carried as active loans. The overall delinquency and default rate of $62.9 \%$ led the authors to suggest that the SBA should specify trade-off 
functions between new-firm utility and failure if EOL loans were to be continued (Bates \& Bradford, 1979). Plagued by high loan default rates, EOL loans in fact fell steadily in number after 1972, and the program was abolished in 1984.

The EOL loan program floundered in part upon a paradox: borrowers repaying their loans came from higher income groups. The truly disadvantaged loan recipients, while clearly eligible, failed in large numbers. When the EOL program served its targeted clientele, few viable businesses emerged (Bates and Bradford, 1979). The program's limited success came about when lending activities missed the targeted client group.

\section{Specialized Small Business Investment Company Loans}

The minority enterprise small business investment company (MESBIC) program was initiated by the SBA in 1970 to alleviate the institutional gap in availability of financial capital believed to be constraining minority business formation and growth nationwide. MESBICs (later renamed SSBICs) would be a "self-help approach to curing poverty and unemployment in the minority

community" (Hansley, 1992, quoted in Bates, 2000). Patient capital - largely loans was made available to disadvantaged minorities and those creating businesses in economically depressed areas. In 1987, 119 SSBICs were active nationwide but 58 of them had gone out of business by 1993. In 1994, the SBA commissioned a study to explore the weak track record of the SSBIC industry, made up of privately owned small-business investment companies receiving funds at subsidized rates from SBA. 
This commissioned study examined all small business investments nationwide made by active SSBICs in 1993 to identify the nature of the assisted firms. Traits of all SSBICs themselves were analyzed to delineate the viable from the nonviable small business investment companies. The typical active SSBIC in 1993 generated 7.33 cents per invested asset dollar while incurring 8.43 cents in expenses to generate those revenues. The resulting spread was minus 1.10 cents before taxes, minus 1.18 cents after taxes, and minus 2.70 cents after writeoffs of liquidated investments (Bates, 2000). Of the 1,101 small-business investments made by SSBICs in 1993, most were in retailing and several lines of services: restaurants, groceries, laundries, and taxis were most numerous, accounting for 655 of all investments. Geographic concentration was pronounced as well: over 70 percent of all investments went to firms operating in four cities - New York, Los Angeles, Dallas, and Detroit. Only 12 of the 101 SSBICs active in 1993 made nearly 63 percent of the 1101 investments. The median SSBIC made three small-business investments in 1993; 47 SSBICs made two or fewer investments (Bates, 1996). Little investment activity went hand-in-hand with negative SSBIC profitability.

The handful of active, successful SSBICs were making few loans to new business startups, the exception being loans to support purchase of New York City taxi medallions. Although SSBICs were authorized to make equity investments in small firms, these accounted for only $10 \%$ of the industry's assets. Successful SSBICs were investing largely by making loans to established, profitable minority-owned businesses seeking to expand. Average loan size was $\$ 80,000$ and the average loan 
recipient generated sales revenues of $\$ 500,000$ prior to receipt of the loan (Bates, 1996).

Discussions with owner/managers of six profitable SSBICs revealed a tension between SBA expectations of how they should invest, versus their strong orientation toward financing business owners who were not really disadvantaged. According to co-owner of TSG Capital, Duane Hill, the SBA wanted TSG to finance unsophisticated business owners. TSG had initially served disadvantaged clients in the late 1970s but had moved up market as a matter of survival, targeting college-graduate owners with corporate work experience. Explaining TSG's strained relations with the SBA, Hill observed "college graduates with corporate experience are not socially or economically disadvantaged" (personal communication, 1995). Reminiscent of the EOL program, success was being achieved by those few SSBICs financing business owners who were not low income and not disadvantaged.

In 1996, the SBA stopped chartering new SSBICs, effectively killing the program. Helping disadvantaged entrepreneurs was still a major objective of the agency. Its focus, however, had shifted to underwriting financing for microenterprise loan programs. Public policy needs to reduce incentives to "marginal entrepreneurs to start businesses by reducing loans, subsidies, regulatory exemptions, and tax benefits that encourage more and more people to start businesses", argues Scott Shane (2009, p.146). "Policy makers believe a dangerous myth. They think that startup companies are a magic bullet that will transform depressed economic regions, generate innovation, create jobs, and conduct all sorts 
of economic wizardry" (p.141). Shane's depiction of entrepreneurship policy appears to describe the SBA's traditional emphasis upon encouraging aspiring disadvantaged entrepreneurs to start new businesses.

\section{Micro-Loan Programs}

Lisa Servon notes that the EOL program was the closest U.S. precedent for the current generation of microenterprise lending programs (1999). Failure of EOL efforts due to high loan default rates and diversion of credit to higher income rather than poor borrowers was overlooked in the late 1980s and 1990s, when the microlending strategy was launched in the U.S. in its current form. Initially, these programs were initiated as locally based responses to a need for better economic options, particularly for people who lacked access to mainstream financial institutions. Born in a political environment where welfare assistance was often vilified, microenterprise lending programs were actively operating in many U.S. cities by 1990 .

The strategy appealed to conservatives who responded to its "hand up rather than hand out" design and to liberals who appreciated the kind of targeted assistance it provided. Partially encouraged by scholarly studies and media coverage describing business success in immigrant enclave communities (Bonacich \& Light, 1988), self-employment was increasingly seen by policy makers as a means of self help. Often targeted to low-income residents of economically depressed inner-city minority communities, self employment and small-business ownership were promoted to assist with revitalizing neighborhoods and alleviating poverty. 
The 1990s generation of U.S. microenterprise programs, in contrast to EOL, also stressed training, which has grown to dominate lending activity.

Aspen Institute surveys of microenterprise programs chronicled rapid growth in the 1990s: Aspen's 1992 directory described and analyzed 84 programs; the 2002 directory profiled 517 active programs. An ambitious study by the Aspen Institute claimed that programs successfully developed viable businesses, created jobs, and alleviated poverty (Edgcomb, et al., 1996). A decade later, the scholarship on U.S. micro-lending had become broader and much more critical. A report issued by AEO (2002) puts the situation in perspective: "If the microenterprise development industry was a single business, then it could be characterized as having low market penetration, high costs, increasing competition, inadequate expenditures in R\&D and technology, and promising but insufficient returns on investment" (p.10). The lending aspect has proven to be the weakest component.

Despite the strong emphasis upon lending to microenterprises owned by economically marginal persons in early literature, few of the clients of most programs actually received loans. Walker \& Blair (2002) estimated that program clients received services other than loans primarily (90\%), most often training; only $10 \%$ received loans. Actual loan volumes achieved by most U.S. programs were quite low. An Aspen Institute study of 554 microenterprise programs listed in the 2002 directory found that only 191 engaged in lending; data describing the 161 providing detailed lending information showed a median number of loans made in 2002 of 13. 
These numbers reflect both an unexpected weak demand for business credit among disadvantaged clients and the substantial programmatic and technical capacity required to engage in lending activity. Complementary research has shown that micro-lenders spend up to four dollars to lend one dollar, making the cost of lending inefficient for most programs (Edgcomb \& Klein, 2005). A practitioner described the frustration of trying to get loans out the door: "what we were finding is that the demand for the loans is not as big as we thought it would be" (Jurik, 2005, p.112).

Program sponsors often expected micro-loan programs to lend aggressively, while realizing low delinquency and default rates. With a few exceptions, those objectives were not achieved in practice: lending to the genuinely disadvantaged produced high costs (relative to benefits) rooted in low loan volume, steep administrative costs per loan, and high default rates (Servon, 2006; AEO, 2002). U.S. micro-lenders were faced with a basic contradiction: the goals of high loan volume and low default, all produced at reasonable costs, simply could not be achieved if the target lending market was restricted to genuinely disadvantaged borrowers. This dilemma sometimes threatened program sustainability and encouraged reorientation away from lending. Difficulties serving poor borrowers caused some programs to shift their lending focus to fit more conventional profiles of successful entrepreneurs.

Contrary to their original expectations, microenterprise program staff were often serving two client pools, one of which was more advantaged and ready to 
borrow. The other client pool was less advantaged and not ready to borrow.

Choosing to serve one of those markets often meant choosing between providing lending and training assistance. Programs serving both markets often segmented their services so that advantaged clients got most of the loans, while the less advantaged got most of the training. Pressure to control loan losses and to keep the high cost of training down reinforced the tendency to lend to better educated, more affluent clients. The lending function simply had not worked out as planned. This reality has had little impact on public policy, which has consistently endorsed micro lending. The American Recovery and Reinvestment Act of 2009, for example, allocated $\$ 30$ million to expand the SBA's micro-loan program.

A recurring problem of poor lending- and business-assistance program performance has often been noted by social scientists. "Because entrepreneurship is seen as a panacea for many of society's ills, elected officials often view helping people to start businesses as a fundamental goal of public policy... Entrepreneurs are thought to take people out of poverty, encourage innovations, create jobs, reduce unemployment, make markets more competitive, and enhance economic growth" (Shane, 2008, p. 146). Yet, the evidence documenting widespread ineffectiveness of lending programs in moving the disadvantaged into business ownership has not typically pinned down exactly why these programs are so often ineffective. 


\section{Entering into Entrepreneurship: What are the Requirements?}

Mainstream literature on entrepreneurship stresses that viable businesses are most often created by owners endowed with human capital, including education, and, or specific skills. Beyond human capital prerequisites, small firm formation often requires financial investment to acquire the tools of the trade. Increased success and survival odds typify well-capitalized small businesses run by owners having the human capital (expertise) appropriate for operating viable ventures (see, for example, Fairlie \& Robb, 2008; Holtz-Eakin, et al., 1994; Bates, 1990; Bruderl, et al., 1992; Fairlie \& Robb, 2007). Absent appropriate human- and financial-capital traits, hard work and initiative alone are often not enough to create viable firms (Servon \& Bates, 1998).

This abbreviated narrative suggests that the likelihood of entry into smallfirm ownership may be heightened among low net-worth individuals if loans were readily accessible. Evidence supporting this position is most compelling in the case of African Americans, the focus of numerous influential empirical studies indisputably documenting their limited access to the financial capital sources commonly used to finance business startup (Blanchflower, et al., 2003; Bates, 1997; Fairlie \& Robb, 2008). The case may be equally compelling for other groups, particularly Latinos, and available evidence suggests that it is (Cavalluzzo \& Wolken, 2005).

Relatively low levels of personal net worth typify black American workers, note Fairlie \& Robb (2007), partially explaining why $3.8 \%$ of them are self- 
employed business owners, compared to $11.6 \%$ of white workers. Bradford (2003) utilized PSID data to measure median net asset holdings of black families headed by employees $(\$ 10,679)$ as opposed to white families with employee heads $(\$ 67,449)$. More recent nationwide data from the U.S. Bureau of the Census, cited by Fairlie \& Robb (2008), indicate median wealth levels of $\$ 6,166$ for black households, one tenth the corresponding $\$ 67,000$ median net worth figure reported by white households. Whether invested directly into small businesses or used as collateral to obtain loans, such huge wealth differences translate into startup capital disparities for aspiring African American entrepreneurs.

Lending discrimination practiced by financial institutions appears to exacerbate Latino- as well as black-white differences in access to financial capital. For both startups and existing small businesses, bankers are the primary source of debt capital, and this capital is more accessible to white entrepreneurs than to similarly situated blacks and Latinos (Blanchflower, et al., 2003; Cavalluzzo \& Wolken, 2005). Restricted access to capital, of course, shapes the scale and industry distribution of planned businesses, often reducing small firm size and scope (Bates, 1997; Fairlie \& Robb, 2007).

An impressive body of scholarship, in summary, suggests that limited access to financial capital shapes the present-day minority business community in multiple ways. To the extent that existing studies of self-employment dynamics agree on anything, the consensus is that growth of entrepreneurship among African Americans and Latinos is thwarted by their relatively low personal wealth levels 
and limited access to debt financing. Our next task is to explore in depth how the financial resources of prospective minority entrepreneurs shape their entry into small-firm ownership, utilizing national representative samples of adults.

\section{Analysis of Self-Employment Entry}

Empirical analyses presented in this section are guided by our desire to unravel a seeming paradox: conventional scholarly wisdom demonstrates that entry into self employment and small-business ownership by prospective minority entrepreneurs (particularly blacks and Latinos) is frustrated by the interrelated phenomena of low household wealth and limited borrowing opportunities, i.e. financial capital constraints. Yet demand for loans has been surprisingly low among micro-lenders, most of which target black and Latino clients. Is the desire to pursue small-business ownership lacking? Are financial constraints less constraining than microenterprise advocates and academics have led us to believe?

This study analyzes data drawn from the SIPP to track self-employment entry among minorities (African Americans, Asians, and Latinos) over three-year periods. Utilizing data from the 1996 and 2001 SIPP panels, we drew a sample of potential entrants, defined as persons who did not report owning a business in the initial period. This sample was initially restricted to African American, Asian, and Latino adults between the ages of 20 and 64, all of whom reported household wealth information. No work restrictions were imposed upon the entrant sample because a significant portion of business entries came from non-employment. The restrictions yielded a sample of 21,065 potential entrants (initially not self employed). African 
Americans accounted for 9,895 of these observations, 9,092 were Hispanics, 2,078 were Asian adults.

The 1996 and 2001 SIPP surveys are rotating panels made up of 12 and nine waves of data, respectively. Surveys (waves) were conducted every four months, tracking the same individuals/households throughout the panel. Because lowincome households were oversampled, sampling weights are used throughout our analysis, making the data nationally representative. Finally, an individual is defined as self employed if he/she reported owning a business and working an average of at least 25 hours per week in that business.

The concept of high- and low-barrier industry subgroups is utilized to explain self-employment dynamics. "Barriers", in this context, refer to the human- and financial-capital resources that self-employment entrants and business owners bring into their ventures. Our primary measure of human capital is one's level of formal education; the financial capital resources brought to the table by potential entrepreneurs are proxied by household net worth.

A high-barrier industry is defined as one requiring advanced educational credentials and, or large-scale investments of startup capital. Common high-barrier industries include professional services, finance, insurance, wholesale, and manufacture. Low-barrier industries, in contrast, are widely accessible to those lacking college educations and significant amounts of financial capital: examples include personal services, repair services and construction fields. Utilizing this 
framework, we demonstrate that determinants of self-employment entry differ sharply across the high- and low-barrier sectors.

Our analysis of SIPP data indicates that the consensus view regarding financial capital constraints and small-firm startup is simplistic: in low-barrier lines of business, higher wealth (and education) levels do not predict higher rates of entry. One's personal net worth amount has almost no explanatory power whatsoever for predicting entry. Those with the strongest educational credentials, furthermore, are even less likely to enter into self employment than high school dropouts. The relevance of the financial- and human-capital resource endowments of potential entrepreneurs applies largely to explaining entry patterns in the highbarrier lines of business. Subsidized lending programs, however, largely finance borrowers seeking entry into low-barrier fields.

Table one reports summary statistics for the wave one potential entrants into self employment. Those entering after wave one are compared to those who did not enter. For comparison purposes, minority entrants and nonentrants are compared not only to each other but to nonminority whites as well. Within these raciallydefined subsets, entrants stand out as more likely to be college graduates and less likely to be high-school dropouts, relative to nonentrants. Substantial household wealth differentials also delineate entrants from nonentrants: minority entrants report mean net assets far above those held by minority nonentrants, but less than the average dollar wealth amount describing white entrants (Table 1). Two dominant patterns apparent in table one statistics are 1) the lower average wealth 
of potential minority entrants and their weaker educational backgrounds, relative to whites, and 2) conditional upon race, the higher mean wealth and educational credentials of entrants, relative to nonentrants.

\section{Table 1 here}

Wealth endowments differ significantly across minority groups, with Asian entrants and nonentrants alike having vastly higher mean household net worth holdings than either blacks or Latinos (Table 2). Educational attainment levels show similar patterns, with Asians standing out as the most highly educated raciallydefined group. Indeed, as other researchers have noted, a comparison of proportions of college graduates reveal that Asian Americans are much more likely than whites to report holding college degrees (Fairlie \& Robb, 2008). In light of this impressive education/personal net worth profile, it is not surprising that Asians enter into self-employment and small business ownership at rates similar to those reported by whites.

Table 2 here

Table three compares entry rates for blacks, Latinos, and Asians to whites, where "entry rate" reflects the probability of becoming self employed during the first nine SIPP sample waves (three years), conditional upon initially not being self employed. Whites exhibit a substantially higher rate of entry $-4.5 \%$ - than blacks, $2.9 \%$ of whom entered self employment; corresponding entry rates for Latinos and Asian Americans were $4.1 \%$ and $4.5 \%$. The breakout of entry rates by low- and highbarrier lines of business, however, reveals a substantially different pattern, 
particularly among the low-barrier fields. Latinos exhibit the highest entry rate into low-barrier industries (3.1\%) and the lowest rate of entry into high-barrier fields (1.1\%) among the racial groups described in table three.

The fact that Latinos overall lag behind whites and Asians in overall entry rates is far less indicative of their interest in pursuit of entrepreneurship than their high rate of entry into the fields where advanced degrees and substantial capital are less important - the low-barrier lines of business. African Americans exhibit entry patterns differing substantially from those typifying Latinos, ranking behind them in low-barrier fields, yet exceeding Latinos entry rates in high-barrier industries. These patterns are explored below.

Table 3 here

Although no clear theoretical basis exists for disaggregating small firms into high- and low-barrier subgroups (Hurst \& Lusardi, 2004), the major industries cluster conveniently into high and low human capital/financial capital subgroups. At the high-barrier end stand manufacture, wholesale, professional services, business services, finance, insurance, and real estate. Low-barrier fields are personal services, repair services, construction, transportation, retail, and misc. services. High-barrier fields are those in which average financial capital investments are highest and/or mean owner years of formal schooling are highest: average owner equity investment in high-barrier fields is in the top one third, relative to all small-business subgroups, and/or owner average years of education is in the top one third. 
We explored the robustness of high/low barrier classifications using U.S. Bureau of the Census Characteristics of Business Owners (CBO) data to classify industry subgroups, using mean owner equity investment at startup, as well as average years of schooling. Retail thus emerged as a high-barrier industry; retail exhibited the highest owner equity and education traits observed in low-barrier fields when SIPP data were utilized to define cutoffs. Retail is the borderline case, not clearly high-or low-barrier. It is noteworthy that industries meeting high-barrier cutoff values for financial capital investment often met cutoff values for high owner human capital as well.

Most Hispanic entrants described in table three were entering businesses in low-barrier fields, with nonminority whites exhibiting the highest concentration (slightly more so than Asians) in industries where high financial- and human-capital levels were the norm. Overall, $42.3 \%$ of African American entrants were in highbarrier lines of business, along with $49.1 \%$ of whites, $25.8 \%$ of Latinos, and $46.3 \%$ of Asians. Our guiding hypothesis is that substantial differences in owner human- and financial-capital resources in different industry subgroups reflect differences in barriers to entry across industries. Potential entrepreneurs with lower educational attainment and net worth holdings tend to enter industries where lower owner education and personal wealth levels (lower barriers) prevail, and vice versa.

A major objective of this study is to investigate the role of personal net worth dollar amount in determining self-employment entry rates among minorities. Utilizing multinomial logit models, explanatory variables include demographic, 
financial- and human-capital traits of adults who were not initially self employed. We treat self employment and industry choices as simultaneous: the three choices are no entry, entry into a low-barrier field, and entry into a high-barrier line of business. Entry is a process shaped by traits and resources of potential entrepreneurs as they interact with business-specific barriers to entry in high- and low-barrier fields. Applicable barriers are hypothesized to vary substantially across small-business sectors, affecting not only the decision to enter but also the type of business entered.

Net worth and educational background predict minority entry into self employment (in the table four logistic regression model) in different ways, depending upon whether entry is into a low- or high-barrier type of firm. Characteristics of potential owners draw entrepreneurs toward some types of small ventures and away from others. High net-worth individuals disproportionately start capital-intensive types of businesses such as manufacturing. High levels of household net worth amount strongly and positively predict entry into high-barrier small businesses, while exhibiting a weaker relationship to low-barrier firm entry less than half the high-barrier magnitude. The implication is that low net-worth holdings only weakly influence one's entry into business fields where low average capitalization levels prevail. Self-employed African Americans and Latinos work disproportionately in low-barrier fields; this finding conflicts with the conventional wisdom that their presence is thwarted by financial-capital constraints. 
Educational levels, in contrast, predict self-employment entry, but not exactly in the manner that conventional wisdom leads us to expect. The collegegraduate variable coefficient stands out as strongly positive for high-barrier fields, yet the exact opposite outcome describes low-barrier industry entry. College graduates positively select into skill-intensive service industries like professional services, while steering clear of low-remuneration fields like personal and repair services. Advanced education, properly understood, positively predicts entry into some lines of small business, while negatively predicting entry into others.

Entry into low-barrier lines of business, as described in table four's logit exercise, suggests that minorities may be pushed in this direction by economic necessity. Thus, the person lacking a high school degree who is out of work is more likely to enter into a low-barrier line of business than the employed college graduate. This finding supports Servon's (2006) argument that there are two categories of entrepreneurs: those who are "true entrepreneurs" who fit a set of characteristics describing an entrepreneurial "type" and those for whom owning a small business is simply their best available option. Traits like gender, age, and work status are statistically significant determinants of low-barrier entry, collectively explaining entry patterns more effectively than household net worth and education traits. Racial differences in the types of industries that potential owners most often enter, furthermore, are important factors for understanding observed racial differences in outcomes.

Table 4 here 
If low net-worth households indeed faced borrowing constraints and were thus unable to finance small-firm startups, it follows that small-firm formation rates would rise as household wealth goes up. Higher wealth levels, after all, serve both as a direct source of startup equity capital, as well as collateral for enhancing one's borrowing power (Bates, 1997). Higher wealth alleviates the capital-constraint problem. Failure to observe a clear, positive relationship between household wealth and entry below the $\$ 150,000$ cutoff for household net worth (Table 4) implies the absence of both equity capital and borrowing constraints for entrants in the lowbarrier lines of business across most of the wealth distribution.

Above the $\$ 150,000$ level, impacts of wealth upon entry into low-barrier lines of business appear to be nontrivial (Table 4), meeting a 10\% cutoff standard regarding statistical significance. Yet we do not view individuals in this wealth bracket as candidates for subsidized lending assistance. For high-barrier industries, possessing household net worth exceeding $\$ 150,000$ is strongly and positively linked to higher rates of entry into entrepreneurship. This observed pattern coincides with Hurst \& Lusardi's conclusion (2004) that the effect of having more wealth on the probability of starting a business is concentrated among the wealthiest ten percent of Americans. High-barrier industry entry rates rise, furthermore, along with increases in levels of educational attainment, with college graduates exhibiting much higher rates of entry than high school dropouts. Thus, the patterns of self-employment entry among those well endowed with human- and financial capital widely identified in past scholarly studies do indeed predict entry into high-barrier fields. 
The Latino trait, in the context of table four's multinomial logit model, has surprising and unexpected explanatory power for predicting entry into low- and high-barrier lines of business. Controlling for education, household net worth, and other traits, Latinos are clearly more likely than Asians (the excluded group) to enter into small-firm ownership and operation. Rather than describing Latinos as less likely to pursue entrepreneurship than Asians (or whites), it is more accurate to portray their entry patterns in terms of the traits that explain variation in such rates. The notion that low self-employment and small-firm ownership is a Latino trait, after all, has much different policy implications than the logit-analysis portrayal of Latinos as a group that is highly inclined to pursue entrepreneurship.

Table four's logistic regression model, finally, is replicated for the full SIPP sample (described in table one), and the results indicate that wealth constraints, education levels, and other factors predict entry for the full sample in the same broad manner discussed above (model not reported). The estimates indicate that the differences in the endowments across ethnic/racial groups explain most of the white-minority differences in entry probabilities into both low- and high-barrier industries, particularly among Hispanics. Among similarly situated non-Hispanic whites and Latinos, there is no gap regarding self-employment entry rates.

A variety of robustness tests were undertaken, as well, to determine whether alterations in table four's logit model specification produced substantive changes in our findings regarding impacts of personal wealth levels upon the likelihood of selfemployment entry. Our criterion for self-employment entry, for example, was 
reduced from 25 hours of work per week in one's own business to 15 hours. Outcomes of these robustness checks indicated most often that personal wealth levels were somewhat stronger predictors of entry into high-barrier firms and weaker predictors of low-barrier entry, in contrast to table four regression findings, in alternate model specifications. Our basic empirical findings regarding the lack of relevance of one's personal wealth holdings for predicting entry into low-barrier lines of business were repeatedly confirmed.

In low-barrier fields, once again, factors predicting higher entry are largely demographic and employment-status related. College graduates are less likely to enter self employment than high-school dropouts and persons with $\$ 40,000$ in personal wealth are no more likely to enter than those possessing $\$ 10,000$ or less. Once other traits are controlled for statistically, whites (the excluded group) and Latinos emerge as the groups most likely to enter both low-barrier and high-barrier industries. Asians and blacks exhibit lower entry rates than whites, all else being equal. It is noteworthy that table three's univariate statistics portrayed Asians as the minority group most likely to enter high-barrier fields.

\section{Role of Differences in Endowments -- Explaining Entry Rate Gaps}

In the low-barrier lines of business where disadvantaged persons living in poverty might realistically seek upward mobility through the route of self employment, the observable characteristics of potential entrepreneurs, particularly household wealth, explain very little of the low-barrier entry rate gap between blacks, Asians, and whites. Differences in net worth across ethnic/racial groups 
simply do not appear to contribute substantively to the differences in low-barrier self-employment entry rates reported in table three. In high-barrier fields, the greater wealth holdings of whites do indeed substantively help to explain their higher self-employment entry rates, relative to blacks and Latinos. The paradox facing subsidized loan programs is the fact that higher entry rates are predicted by financial resources only at the high end of the wealth distribution. In the low-barrier fields accessible to the target market of most of these programs, small increases in financial resources do not appear to impact on the likelihood of entry into self employment.

To address the specific role of wealth on high-barrier entry, we estimated a parsimonious logit model, including only our wealth controls (model not reported). Results indicate that the difference in net worth alone between Latinos and whites explains roughly $1 / 3$ of high-barrier entry rate gap. The same exercise, but comparing African-Americans and whites, indicates that wealth differences between the two groups account for roughly $1 / 3$ of the high-barrier entry gap. Replicating this exercise for low-barrier lines of business indicated that wealth differences explained less than two percent of the black/white and Latino/white entry rate gaps. Since education and net worth are positively correlated, the contribution of wealth in explaining the gap in self-employment entry rates may capture the impact of education.

To investigate the combined contribution of education and net worth for explaining gaps in high-barrier enterprise entry rates, we estimate a specification 
that includes both types of controls. The results (not reported) indicate that slightly more than $75 \%$ of the Latino/white high-barrier entry-rate gap is explained by differences in educational attainment and wealth alone. The contribution of these two factors in explaining the white-black high-barrier entry rate gap is about $65 \%$. Overall, wealth differences clearly are strongly related to the lower black and Latino presence in high-barrier lines of business ownership, but educational differences are a more important cause of their lower observed self-employment entry rates.

\section{Concluding Observations}

On balance, this study has found some evidence consistent with the conventional wisdom that financial constraints retard self-employment entry among blacks and Latinos, but this constraint does not appear to impact the lowbarrier lines of business where micro-lending-targeted clienteles - disadvantaged persons - might realistically expect to become small business owners

The human- and financial-capital constraints widely cited as determinants of entry patterns in fact operate quite differently in high- and low-barrier business segments. Self-employment entry has been most often examined empirically in onesize-fits-all econometric models, but this approach cannot capture key entry dynamics. This is because industry context heavily shapes the impacts of owner resource endowments on small firm entry. Limitations of one-size-fits-all models are rooted in the fact that major differences in entry barriers typify different industry subgroups. 
Our findings from analysis of SIPP data indicate that the relationship between financial capital constraints and entry into the low-barrier lines of business conforms neither to the scholarly conventional wisdom nor to the assumptions justifying subsidized lending programs. Our analysis yields no evidence to support the contention that capital constraints keep disadvantaged borrowers from starting businesses in low-barrier fields. Underutilized loan funds at many U.S. MLPs provide further support for our conclusion that the strategy of providing small business loans, on its own, will not significantly increase the number of business starts among disadvantaged entrepreneurs.

According to the AEO, "many microenterprise programs do not substantively research clients' or potential clients' needs or diversify products to attract and retain customers" (2002, p.9). On the lending side, product lines are narrow and often fail to address the diverse nature of credit needs. The very small business loans micro lenders commonly provide have relatively high costs and serve a small niche. Evidence of broad demand for financial services comes indirectly from the growth of fringe financial services, such as check cashing companies, payday lenders, and rent-to-own operations (Carr \& Kolluri, 2001; Stegman \& Faris, 2003). Mainstream lenders are beginning to tap into these markets as technological advances and credit scoring enable them to serve this market more cheaply.

If lending is to be pursued, more appropriate targeting of microenterprise business lending is essential. For example, an appropriate target market might exist among ongoing small businesses seeking loans to finance expansion of their 
operations. Shane observes that most startups require little capital, noting that the process of growth among young firms is what makes cash flow go negative and makes external financing important (2008). Policy makers, funders, and the U.S. micro lenders need to rethink the structure and offerings of these organizations, and to gear them more specifically to the actual challenges facing their target market. 


\section{References}

Association for Enterprise Opportunity. (2002). National microenterprise strategy: Capturing the promise of microenterprise development in the United States. Arlington, VA: author.

Bates, T. (1990). Entrepreneur human capital inputs and small business longevity, Review of Economics and Statistics, 72, 551-59.

Bates, T. (1996). An analysis of the SSBIC program: Problems and prospects. (Research contract 94-001, final report). Washington, D.C.: U.S. Small Business Administration.

Bates, T. (1997.) Race, self-employment and upward mobility. Baltimore: Johns Hopkins University Press.

Bates, T. (2000). Financing the development of urban minority communities. Economic Development Quarterly, 14, 227-41.

Bates, T., \& Bradford, W. (1979). Financing black economic development. New York: Academic Press.

Blanchflower, D., Levine, P., \& Zimmerman, D. (2003) Discrimination in the small business credit market. Review of Economics and Statistics, 85, 930-43.

Bonacich, E., \& Light, I. (1988). Immigrant entrepreneurs: Koreans in Los Angeles 1965-1982. Berkeley: University of California Press.

Bruderl, J., Preisendorfer, P., \& Ziegler, R. (1992). Survival chances of newly founded organizations, American Sociological Review, 57, 227-42.

Carr, J., \& Kolluri, L. (2001). Financial services in distressed communities: Issues and answers. Washington, D.C: Fannie Mae Foundation.

Cavalluzzo, K., \& Wolken, J. (2005). Small business loan turndowns, personal wealth and discrimination, Journal of Business, 78, 2153-78.

Deparle J. (1998). What welfare-to-work really means. The New York Times Magazine, December 20, 50, 89, 90.

Edgcomb, E., Klein, J. \& Clark, P. (1996). The practice of microenterprise in the U.S. Washington, D.C.: Aspen Institute.

Edgcomb, E., \& Joyce Klein. (2005). Opening opportunities, building ownership: Fulfilling the promise of microenterprise in the United States. Washington, DC: Field. 
Fairlie, R. (1999). The absence of the African-American owned business: An analysis of the dynamics of self-employment. Journal of Labor Economics, 17, 80-108.

Fairlie, R. \& Robb, A. (2007). Why Are black-owned businesses less successful than white-owned businesses: The role of families, inheritances, and business human capital Journal of Labor Economic, 25, 289-324.

Fairlie R., \& Robb, A. (2008). Race and entrepreneurial success. Cambridge: MIT Press.

Holtz-Eaken, D, Joulfaian, D., \& Rosen, H. (1994). Entrepreneurial decisions and liquidity constraints. Rand Journal of Economics, 25, 334-47.

Hurst, E., \& Lusardi, A. (2004). Liquidity constraints, household wealth, and entrepreneurship. Journal of Political Economy, 112, 319-47.

Jurik, N. (2005). Bootstrap dreams: U.S. microenterprise development in an era of welfare reform. Ithaca: Cornell University Press.

Servon, L. (1999). Bootstrap capital: Microenterprises and the American poor. Washington, DC: Brookings Institution Press.

Servon, L. (2006). Microenterprise development in the United States: Current challenges and new directions. Economic Development Quarterly, 20, 351-67.

Servon, L., \& Bates, T. (1998). Microenterprise as an exit route from poverty. Journal of Urban Affairs, 20, 419-41.

Shane, S. 2008. The illusions of entrepreneurship. New Haven: Yale University Press.

Shane, S. (2009). Why encouraging more people to become entrepreneurs is bad public policy. Small Business Economics, 33, 141-9.

Stegman, M., \& Faris, R. (2003). Payday lending: a business model that encourages chronic borrowing. Economic Development Quarterly, 17, 8-32.

U.S. Small Business Administration. (1970). The SBA: What it is, what It does. Washington, D.C.: U.S. Government Printing Office.

Walker, B., \& Blair, A. (2002). The 2002 directory of U.S. microenterprise programs. Washington, D.C.: Aspen Institute. 
Table 1: Comparison of Nonminority and Minority Entrants and Non-entrants Potential Entrants Only: Summary Statistics, Sample Means, by Entry and No Entry.

\begin{tabular}{|c|c|c|c|c|}
\hline & \multicolumn{2}{|c|}{ Non-Hispanic White } & \multicolumn{2}{|c|}{ Minority } \\
\hline & No Entry & Entry & No Entry & Entry \\
\hline Years of Education & 13.41 & $14.10^{\star}$ & 11.75 & $12.40^{\star}$ \\
\hline High School Dropout & 0.08 & $0.06^{*}$ & 0.27 & $0.22^{*}$ \\
\hline High School Graduate & 0.33 & $0.27^{*}$ & 0.33 & $0.30^{*}$ \\
\hline Some College & 0.32 & 0.31 & 0.27 & 0.27 \\
\hline College Graduate & 0.26 & $0.36^{*}$ & 0.14 & $0.21^{*}$ \\
\hline Age & 40.68 & $39.30^{*}$ & 38.31 & 38.40 \\
\hline Female & 0.54 & $0.43^{*}$ & 0.57 & $0.43^{*}$ \\
\hline Married & 0.64 & $0.66^{*}$ & 0.49 & $0.59^{*}$ \\
\hline Number of Children & 0.79 & $0.90^{*}$ & 1.18 & 1.18 \\
\hline Number of Persons in Household & 2.97 & $3.04^{\star}$ & 3.67 & 3.76 \\
\hline Urban Resident & 0.73 & $0.75^{\star}$ & 0.87 & $0.91^{*}$ \\
\hline Immigrant & 0.04 & 0.04 & 0.32 & $0.42^{\star}$ \\
\hline Years Since Immigration & 19.25 & $16.60^{*}$ & 14.91 & 15.03 \\
\hline Not Working & 0.25 & 0.24 & 0.33 & 0.35 \\
\hline Wage/Salary Sector & 0.75 & 0.76 & 0.67 & 0.65 \\
\hline Job Tenure (years) & 5.66 & $4.26^{*}$ & 4.17 & $3.10^{\star}$ \\
\hline Annual Earnings & 24,944 & $29,788^{*}$ & 16,806 & $20,940^{*}$ \\
\hline Household Net Worth & 150,656 & $180,183^{*}$ & 50,850 & $86,670^{*}$ \\
\hline Less Than $\$ 10,000$ & 0.27 & 0.26 & 0.51 & $0.45^{\star}$ \\
\hline Between $\$ 10,000$ and $\$ 50,000$ & 0.21 & $0.17^{*}$ & 0.23 & 0.22 \\
\hline Between $\$ 50,000$ and $\$ 150,000$ & 0.26 & 0.24 & 0.17 & 0.17 \\
\hline More Than $\$ 150,000$ & 0.27 & $0.32^{*}$ & 0.09 & $0.17^{\star}$ \\
\hline Number of Individuals & 53,893 & 2,544 & 20,323 & 742 \\
\hline
\end{tabular}

Source: 1996 and 2001 Survey of Income and Program Participation.

Note: * indicates that the within ethnic group mean difference between entrants and non-entrants is statistically significant at the $5 \%$ significance level. 
Table 2: Comparison of Entrants and Non-entrants

Potential Entrants Only: Summary Statistics, Sample Means, by Entry and No Entry.

\begin{tabular}{|c|c|c|c|c|c|c|}
\hline & \multicolumn{2}{|l|}{ Black } & \multicolumn{2}{|l|}{ Latino } & \multicolumn{2}{|l|}{ Asian } \\
\hline & No Entry & Entry & No Entry & Entry & No Entry & Entry \\
\hline Years of Education & 12.47 & $13.50^{*}$ & 10.50 & $11.13^{\star}$ & 13.70 & $14.64^{*}$ \\
\hline High School Dropout & 0.17 & $0.09 *$ & 0.40 & 0.36 & 0.12 & $0.04^{*}$ \\
\hline High School Graduate & 0.39 & $0.31^{*}$ & 0.29 & 0.30 & 0.20 & 0.23 \\
\hline Some College & 0.31 & 0.34 & 0.22 & 0.22 & 0.25 & 0.23 \\
\hline College Graduate & 0.13 & $0.26^{*}$ & 0.08 & 0.11 & 0.42 & 0.49 \\
\hline Age & 39.73 & 39.99 & 36.70 & 36.91 & 38.49 & 39.53 \\
\hline Female & 0.61 & $0.43^{*}$ & 0.54 & $0.45^{\star}$ & 0.58 & $0.37^{\star}$ \\
\hline Married & 0.38 & $0.50 *$ & 0.57 & 0.62 & 0.65 & 0.74 \\
\hline Number of Children & 1.05 & 0.94 & 1.37 & 1.39 & 0.99 & 1.07 \\
\hline Number of Persons in Household & 3.29 & 3.20 & 4.09 & 4.18 & 3.70 & 3.76 \\
\hline Urban Resident & 0.83 & $0.90 *$ & 0.89 & 0.89 & 0.96 & 0.99 \\
\hline Immigrant & 0.06 & $0.10^{*}$ & 0.49 & $0.57^{*}$ & 0.80 & 0.74 \\
\hline Years Since Immigration & 15.28 & 16.60 & 15.39 & 14.85 & 13.51 & 15.05 \\
\hline Not Working & 0.33 & 0.29 & 0.34 & $0 *$ & 31 & 32 \\
\hline
\end{tabular}




\begin{tabular}{lcccccc} 
Wage/Salary Sector & 0.67 & 0.71 & 0.66 & $0.60^{*}$ & 0.69 & 0.68 \\
Job Tenure (years) & 4.96 & $4.07^{*}$ & 3.46 & $2.44^{*}$ & 3.48 & 2.78 \\
Annual Earnings & 16,773 & $24,059^{*}$ & 15,195 & 16,084 & 24,038 & 30,965 \\
& & & & & & \\
Household Net Worth (\$) & 37,399 & $61,298^{*}$ & 46,765 & 59,910 & 133,856 & $273,804^{*}$ \\
Less Than $\$ 10,000$ & 0.52 & $0.44^{*}$ & 0.54 & 0.51 & 0.30 & $0.21^{\star}$ \\
Between $\$ 10,000$ and $\$ 50,000$ & 0.24 & 0.25 & 0.22 & 0.20 & 0.22 & 0.16 \\
Between $\$ 50,000$ and $\$ 150,000$ & 0.17 & 0.17 & 0.16 & 0.16 & 0.21 & 0.19 \\
More Than $\$ 150,000$ & 0.06 & $0.14^{*}$ & 0.08 & $0.12^{\star}$ & 0.27 & $0.44^{\star}$ \\
Number of Individuals & & & & & & \\
\hline Source: 1996 and 2001 Survey & 9,613 & 282 & 8,723 & 369 & 1,987 & 91 \\
\hline
\end{tabular}

Source: 1996 and 2001 Survey of Income and Program Participation.

Note: * indicates that the within ethnic group mean difference between entrants and non-entrants is statistically significant at the $5 \%$ significance level. 


\begin{tabular}{lcccc}
\hline & White & African & Latino & Asian \\
& \multicolumn{4}{c}{ American } \\
\hline Overall Entry Rate (3 Year) & $4.5 \%$ & $2.9 \%$ & $4.1 \%$ & $4.5 \%$ \\
& & & & \\
Entry Rates by Industry Group & & & & \\
Entry into Low Barrier Industry") & $2.3 \%$ & $1.7 \%$ & $3.1 \%$ & $2.4 \%$ \\
Percent of all Entrants & 50.9 & 57.7 & 74.2 & 53.7 \\
& & & & \\
Entry into High Barrier Industry & $2.2 \%$ & $1.2 \%$ & $1.1 \%$ & $2.1 \%$ \\
Percent of all Entrants & 49.1 & 42.3 & 25.8 & 46.3 \\
& & & & \\
Number of Individuals & 56,437 & 9,895 & 9,092 & 2,078 \\
\hline
\end{tabular}

Source: 1996 and 2001 Survey of Income and Program Participation.

i) Low-barrier industries: personal services, repair services, misc. services, construction, transportation, retail.

ii) High-barrier industries: professional services, finance, insurance, and real estate, business services, manufacture, wholesale. 
Table 4: Multinomial Logistic Regression Model of Entry: Minorities Only (High-Low Barriers) - Marginal Effects

\begin{tabular}{|c|c|c|c|c|}
\hline \multirow[t]{3}{*}{ Variable } & \multicolumn{2}{|c|}{ Low Barrier } & \multicolumn{2}{|c|}{ High Barrier } \\
\hline & Marginal & Z- & Marginal & Z- \\
\hline & Effects & Statistic & Effects & Statistic \\
\hline Black & -0.001 & -0.25 & 0.005 & 1.35 \\
\hline Hispanic & 0.005 & 2.00 & 0.007 & 1.96 \\
\hline Female & -0.019 & -10.55 & -0.004 & -1.79 \\
\hline High School Graduate & 0.002 & 1.22 & 0.008 & 2.48 \\
\hline Some College & 0.001 & 0.34 & 0.019 & 4.42 \\
\hline College Graduate & -0.004 & -2.21 & 0.030 & 4.25 \\
\hline Age & 0.001 & 3.77 & 0.003 & 6.07 \\
\hline Age Squared/100 & -0.002 & -3.62 & -0.004 & -5.98 \\
\hline Married & 0.002 & 1.33 & 0.002 & 0.90 \\
\hline Number of Children & -0.0001 & -0.16 & 0.0003 & 0.28 \\
\hline Number of Persons in Household & 0.0003 & 0.70 & -0.0001 & -0.15 \\
\hline Urban Resident & 0.002 & 1.50 & -0.001 & -0.39 \\
\hline Immigrant & 0.005 & 1.76 & 0.008 & 1.83 \\
\hline Years Since Immigration & -0.0001 & -0.26 & 0.0001 & 0.42 \\
\hline Not Working & 0.005 & 2.88 & 0.009 & 3.47 \\
\hline Job Tenure & 0.00001 & 0.07 & -0.002 & -4.93 \\
\hline Job Tenure Squared/100 & -0.001 & -0.95 & 0.006 & 4.25 \\
\hline Between $\$ 1$ and $\$ 10,000$ & -0.001 & -0.44 & -0.001 & -0.41 \\
\hline
\end{tabular}




\begin{tabular}{lcccc}
\multicolumn{1}{c}{ Between $\$ 10,000$ and $\$ 25,000$} & 0.003 & 1.09 & -0.003 & -1.05 \\
Between $\$ 25,000$ and $\$ 50,000$ & 0.002 & 0.68 & 0.0003 & 0.07 \\
Between $\$ 50,000$ and $\$ 150,000$ & 0.003 & 1.39 & 0.003 & 1.08 \\
More Than $\$ 150,000$ & 0.006 & 1.92 & 0.011 & 2.30 \\
& & & & \\
SIPP 2001 & -0.0004 & -0.37 & 0.004 & 1.97 \\
& & & & \\
Log Likelihood & & $-3,543$ & \\
Number of Observations & \multicolumn{2}{c}{21,065} \\
\hline
\end{tabular}

Note: The reference outcome is "no entry".

Source: 1996 and 2001 Survey of Income and Program Participation. 